\title{
ABPP MOTION SIMULATOR BASED ON 3D ENC
}

\begin{abstract}
A research focused on development of numerical model of a sea area destined for a motion simulator of an Autonomous Biomimetic Underwater Vehicle (ABPP) is presented in the paper. There are purpose, construction and functionality of the ABPP motion simulator generally characterized in the introduction. The first part contains description of a method of creating the sea area model based on the data included in the Electronic Navigational Chart (ENC). A method of displaying the sea area model in the ABPP motion simulator, with a use of the Open GL graphic library, is described in the second part. Finally, there are conclusions drawn from the executed research given at the end.
\end{abstract}

\section{Keywords:}

ABPP motion simulator, sea area model, Electronic Navigational Chart 3D.

\section{INTRODUCTION}

These days, simulation studies on the system properties, with a use of computer and based on a mathematic model of the reality, is a basis for conceptual work in industry. It results, first of all, from the fact that they allow the costs of solutions' development to be lowered and the time of the product introduction into the market to be shortened.

That is why development of the Autonomous Biomimetic Underwater Vehicle's (ABPP) motion simulator was one of the aims of the conceptual work conducted within the frames of the development project no. DOBR-BIO4/ 033/13015/2013 entitled 'Autonomous underwater vehicles with variable frequency silent drives for underwater recons'. 
That simulator was to be used for displaying the ABPP motion in sea environment (sea area) and, in a later stage, for training operators before they start working with real equipment. It was to enable performance of tests of the ABPP navigational systems (also autonomous ones) constructed with a use of navigational devices (echo-sounding ones in particular) and interacting with the sea area model (consisting of the seabed surface, aids to navigation, breakwaters etc.).

The paper is presenting description of results of works that were aimed on development of the sea area 3D model based on selected geospatial data included in ENC and on execution of a graphical 3D interface for the scene and ABPP visualisation.

\section{DEVELOPMENT OF THE SEA AREA MODEL}

The 3D model of the sea area was developed based on the geospatial data encoded in ENC, in spatial objects, describing [IHO, 2002; Naus, Jankiewicz, 2006; Naus, 2015; Naus, Wąż, 2016]:

Elements of sea port infrastructure

Land area (Acronym: LNDARE, Code: 71)

Definition:

The solid portion of the Earth's surface, as opposed to sea water.

Shoreline construction (Acronym: SLCONS, Code: 122)

Definition:

A fixed (not afloat) artificial structure between the water and the land, i.e. a man-made coastline.

Floating dock (Acronym: FLODOC, Code: 57)

Definition:

A form of dry dock consisting of a floating structure of one or more sections which can be partly submerged by controlled flooding to receive a vessel, then raised by pumping out the water so that the vessel's bottom can be exposed.

Hulk (Acronym: HULKES, Code: 65)

Definition:

A permanently moored ship. 
Mooring/Warping facility (Acronym: MORFAC, Code: 84)

Definition:

The equipment or structure used to secure a vessel.

Pontoon (Acronym: PONTON, Code: 95)

Definition:

A floating structure, usually rectangular in shape which serves as landing, pier head or bridge support.

Seabed shape

Depth area (Acronym: DEPARE, Code: 42)

Definition:

A depth area is a water area which depth is within a defined range of values.

Dredged area (Acronym: DRGARE, Code: 46)

Definition:

An area of the bottom of a body of water which has been deepened by dredging.

Aids to navigation

Beacon, cardinal (Acronym: BCNCAR, Code: 5)

Definition:

A cardinal beacon is used in conjunction with the compass to indicate where the mariner may find the best navigable water. It is placed in one of the four quadrants (North, East, South and West), bounded by intercardinal bearings from the point marked.

Beacon, isolated danger (Acronym: BCNISD, Code: 6)

Definition:

An isolated danger beacon is a beacon erected on an isolated danger of limited extent which has navigable water all around it.

Beacon, lateral (Acronym: BCNLAT, Code: 7)

Definition:

A lateral beacon is used to indicate the port or starboard hand side of the route to be followed. It is generally used for well defined channels and in conjunction with a conventional direction of buoyage. 
Beacon, safe water (Acronym: BCNSAW, Code: 8)

Definition:

A safe water beacon may be used to indicate that there is navigable water around the mark.

Beacon, special purpose/general (Acronym: BCNSPP, Code: 9)

Definition:

A special purpose beacon is primarily used to indicate an area or feature the nature of which is apparent from reference to a chart, Sailing Directions or Notices to Mariners.

Buoy, cardinal (Acronym: BOYCAR, Code: 14)

Definition:

A cardinal buoy is used in conjunction with the compass to indicate where the mariner may find the best navigable water. It is placed in one of the four quadrants (North, East, South and West), bounded by inter-cardinal bearings from the point marked.

Buoy, installation (Acronym: BOYINB, Code: 15)

Definition:

An installation buoy is a buoy used for loading tankers with gas or oil.

Buoy, isolated danger (Acronym: BOYISD, Code: 16)

Definition:

An isolated danger buoy is a buoy moored on or above an isolated danger of limited extent which has navigable water all around it.

Buoy, lateral (Acronym: BOYLAT, Code: 17)

Definition:

A lateral buoy is used to indicate the port or starboard hand side of the route to be followed. It is generally used for well defined channels and in conjunction with a conventional direction of buoyage.

Buoy, safe water (Acronym: BOYSAW, Code: 18)

Definition:

A safe water buoy is used to indicate that there is navigable water around the mark.

Buoy, special purpose/general (Acronym: BOYPP, Code: 19)

Definition:

A special purpose buoy is primarily used to indicate an area or feature the nature of which is apparent from reference to a chart, Sailing Directions or Notices to Mariners. 
All listed 2D ENC objects were converted, with a use of a proprietary application, onto the 3D objects which geometries were represented by Triangular Irregular Networks (TIN) [Naus, Wąż, 2012; www.geom, 2016]. It was assumed in the conversion method that apexes of the networks' triangles would be located just in nodal points of the ENC surface objects (LNDARE, SLCONS, FLODOC, HULKES, MORFAC, PONTON, DEPARE, DRGARE) so that the new geometrical description would not be affected in respect to accuracy and would keep the initial courses of structural lines (in particular of: isobathic lines and edges of coasts). In addition, in was assumed that isolated nodes of the ENC point objects (BCNCAR, BCNISD, BCNLAT, BCNSAW, BCNSPP, BOYCAR, BOYINB, BOYISD, BOYLAT, BOYSAW, BOYPP) would make geometrical centres of the TINs representing the aids to navigation in a form of solids made out of cylinders and spheres.

Main window of the proprietary application for creating the sea area model based on the TIN is presented on Figure 1.

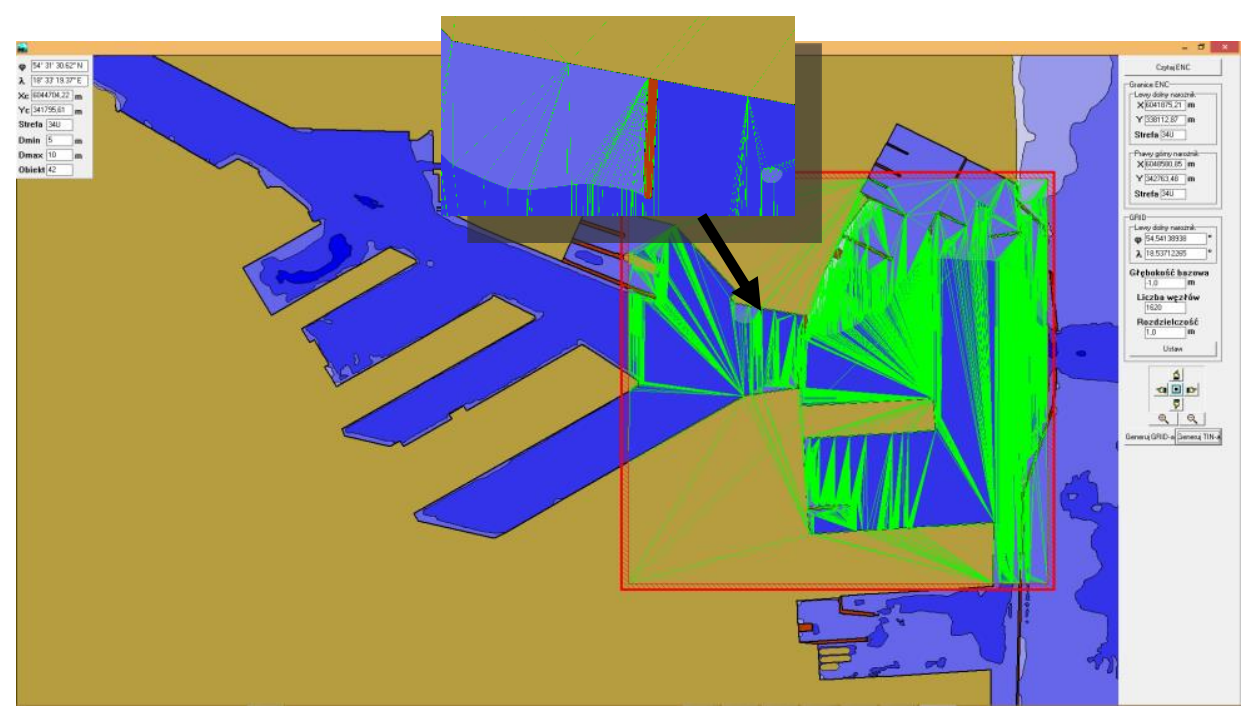

Fig. 1. Main window of application for creating sea area model based on TIN

\section{DISPLAYING THE SEA AREA MODEL}

The ABPP motion simulator is based on the computer application using the 3D model of the sea area created both for presentation and interaction with the navigational devices and the ABPP itself. The application was elaborated in the integrated 
development environment $\mathrm{C}++$ Builder 6.0, with a use of the OpenGL graphic library [www.embarcadero, 2016; www.opengl, 2016]. Ultimately, it will be designed for the Windows 7 and 8 operating system [www.windows, 2016].

A process of generating the $3 \mathrm{D}$ picture of the sea area model under execution of the application may be divided into four stages, as below:

- building lists of triangles describing geometries of the 3D objects;

- modelling properties of materials covering surfaces of the triangles;

- modelling lighting of the scene;

- visualisation, on the monitor screen, the modelled 3D scene.

Main window of the ABPP simulator's application, with the $3 \mathrm{~B}$ visualisation of the sea area model, is presented on Figure 2.

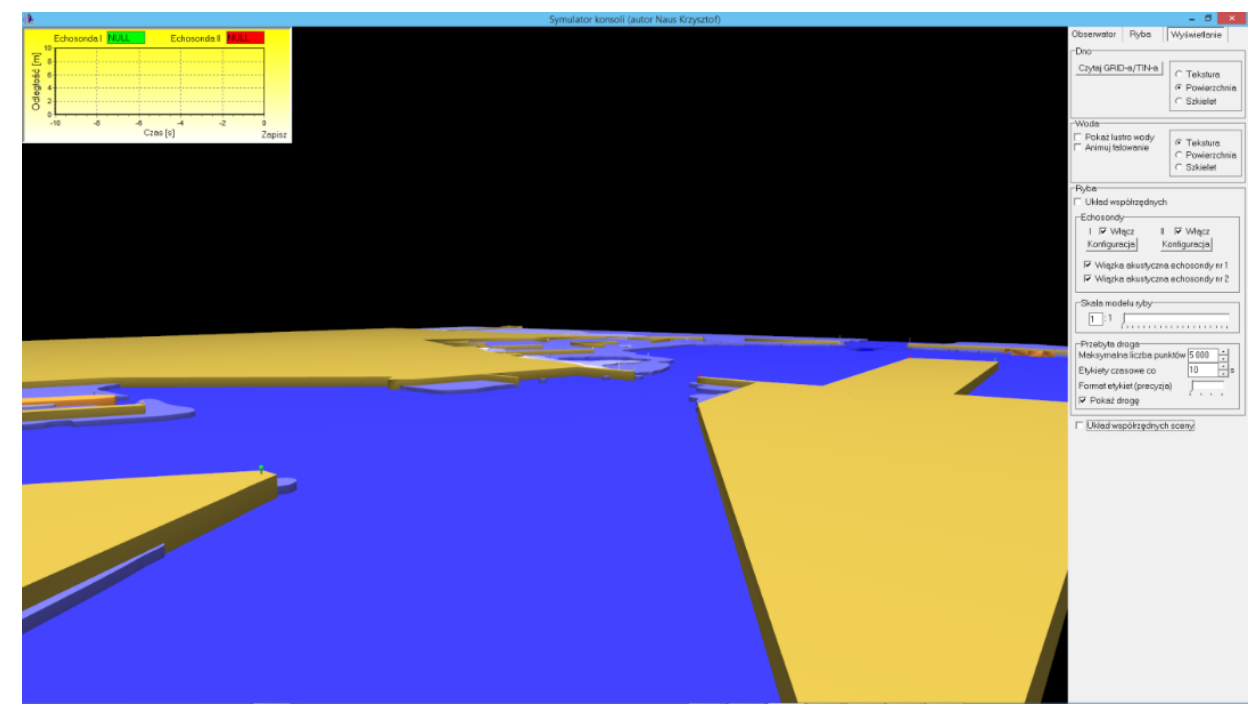

Fig. 2. Visualisation of sea area model

The lists of triangles describing geometries of the 3D objects are built based on data provided by a loaded file of TIN type, earlier prepared with a use of the proprietary application.

Modelling of the material properties consists in determining the kind and reflexive qualities (in respect to sources of light, properties of own light emission and gloss level) of the materials covering the triangles' surfaces. 
a)

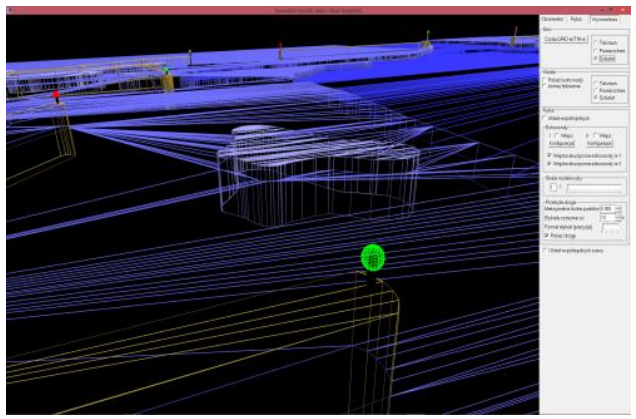

b)

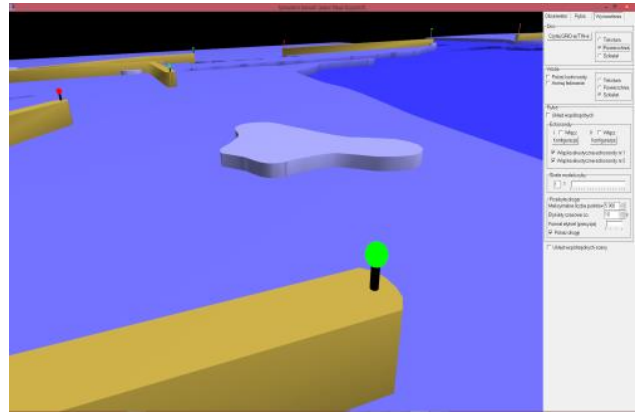

Fig. 3. Visualisation of sea area model: a) in form of TIN; b) in form of plane

Modelling of the lighting consisted in determining three different types of light, as below:

- ambient light — misting identically on all surfaces from all directions;

- diffuse light — which rays radiate evenly in all directions from one point;

- specular light - reflecting on the surface as in mirror.

Visualisation, on the monitor screen, of the modelled 3D scene is executed for the set spatial parameters of camera (Fig. 4), i.e.:

- position of the observer (camera), described with ellipsoidal (UTM) and local (XYZ) coordinates [Felski, 1991];

- the camera orientation, described with angles of pitch and roll and with course.

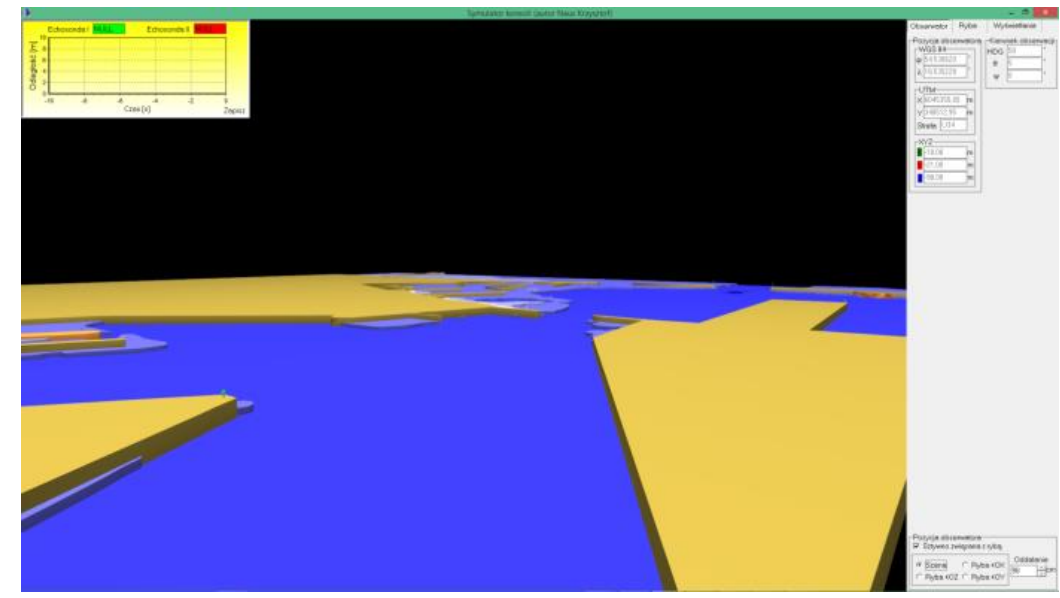

Fig. 4. Tab 'Display' with camera's spatial parameters 


\section{CONCLUSIONS}

Building and visualising the sea area model is one of the important research topics for most institutions linked to activities at sea. This is mainly due to the increasingly widespread use of 3D marine models in simulations and development of automatic methods for acquiring and processing hydrographical source data. In respect to the source of data regarding sea environment, by virtue of high requirements with regard to the detailedness and accuracy of the sea area model reconstruction, it is justified to make use of ENCs authorized by national hydrographic offices.

However, one should have in mind the fact that the data processing, aimed at creation and visualisation of the sea area 3D model under execution with a use of the data included in ENC, is a compute-intensive and time consuming task. On one hand - during creation of the model, it requires implementation of very complicated functions converting the vector geometric data, encoded in accordance with S-57 standard, into the form of TIN. On the other hand - during visualisation of the model - it needs optimal use of functions of the graphic libraries destined for modelling the material properties and lighting of the scene, as well as the functions for determining position of the so-called camera and for changing the scene view all using complex matrixes of geometric conversions.

\section{REFERENCES}

[1] Felski A., The concept of the navigation in the orthocartesian space, [in Polish], 'Zeszyty Naukowe AMW', 1991, No. 110A.

[2] IHO, Special Publication No. S-57, Appendix A, Chapter 1, Object Classes, Published by the International Hydrographic Bureau, Monaco 2002.

[3] IHO, Special Publication No. S-57, Appendix B1, ENC Product Specification, Published by the International Hydrographic Bureau, Monaco 2002.

[4] Naus K, Jankiewicz M., ENC as a source of hydrographic data for paper maps, 'Zeszyty Naukowe AMW', 2006, No. 166K/1, pp.163-173.

[5] Naus K., Electronic navigational chart as an equivalent to image produced by hypercatadioptric camera system, 'Polish Maritime Research, 2015, Vol. 22, No. 1, pp. 3-9.

[6] Naus K., Jankiewicz M., The geometry assembling of spatial objects in electronic navigational chart, IV International Scientific and Technical Conference EXPLO-SHIP, Świnoujście - Kopenhaga 2006, pp. 237-246. 
[7] Naus K., Wąż M., A simplified navigational chart pyramid dedicated to an autonomous navigational system, 'Polish Hyperbaric Research', 2012, Vol. 40, No. 3, pp. 139-161.

[8] Naus K., Wąż M., Precision in determining ship position using the omnidirectional map to visual shoreline image comparative method, 'Journal of Navigation', 2016, Vol. 69, Issue 2, pp. 391-413.

[9] www.embarcadero.com.pl/ [access 20.08.2016].

[10] www.geom.uiuc.edu/ samuelp/del_project.html [access 20.08.2016].

[11] www.windows.microsoft.com/pl-pl/windows/home [access 20.08.2016].

[12] www.opengl.org/ [access 20.08.2016].

Received September 2016

Reviewed August 2017

Published 04.10.2017

\section{KRZYSZTOF NAUS}

Polish Naval Academy

Śmidowicza 69 Str., 81-127 Gdynia, Poland

e-mail: k.naus@amw.gdynia.pl

\section{PIOTR ZWOLAN}

Polish Naval Academy

Śmidowicza 69 Str., 81-127 Gdynia, Poland

e-mail: p.zwolan@amw.gdynia.pl

\section{STRESZCZENIE}

W artykule przedstawiono badania mające na celu opracowanie numerycznego modelu akwenu morskiego przeznaczonego dla symulatora ruchu autonomicznego biomimetycznego pojazdu podwodwodnego (Autonomous Biomimetic Underwater Vehicle - ABPP). We wstępie scharakteryzowano ogólnie przeznaczenie, budowę oraz funkcjonalność symulatora ruchu ABPP. Pierwsza część zawiera opis metody tworzenia modelu akwenu morskiego na podstawie danych zawartych w elektronicznej mapie nawigacyjnej (Electronic Navigational Chart - ENC). W części drugiej opisano metodę zobrazowania modelu akwenu morskiego w symulatorze ruchu ABPP przy wykorzystaniu biblioteki graficznej OpenGL. Na końcu przedstawiono wnioski z przeprowadzonych badań. 